\title{
Two Cases Report of Myxoid Degeneration of the Auricular Cartilage
}

\author{
Dong Kun Lee ${ }^{1}$, Yeo Myeong Lee ${ }^{1}$, Kyung Han Nam², and Kyung Wook Heo ${ }^{1}$ \\ ${ }^{1}$ Department of Otolaryngology-Head and Neck Surgery, Inje University College of Medicine, Busan Paik Hospital, Busan; and \\ ${ }^{2}$ Department of Pathology, Inje University College of Medicine, Haeundae Paik Hospital, Busan, Korea
}

\section{이개 연골의 점액 변성 2 예}

\author{
이동근 ${ }^{1} \cdot$ 이여명 $^{1} \cdot$ 남경한 $^{2} \cdot$ 허경욱 $^{1}$ \\ 인제대학교 의과대학 부산백병원 이비인후-두경부외과학교실, ${ }^{1}$ 인제대학교 의과대학 해운대백병원 병리과학교실 ${ }^{2}$
}

\author{
Received January 26, 2017 \\ Revised April 5, 2017 \\ Accepted April 14, 2017 \\ Address for correspondence \\ Kyung Wook Heo, MD, PhD \\ Department of Otolaryngology- \\ Head and Neck Surgery, \\ Inje University College of Medicine, \\ Busan Paik Hospital, \\ 75 Bokji-ro, Busanjin-gu, \\ Busan 47392, Korea \\ Tel $+82-51-890-5379$ \\ Fax $+82-51-892-3831$ \\ E-mail heokw96@daum.net
}

\begin{abstract}
Myxoid degeneration (MD) in the cartilage results from the accumulation of hyaluronic acid in the stroma. However, it is rarely found in the auricular cartilage, with only one published report to date. This article describes two histologically confirmed cases of MD of the auricle that was excised with favorable aesthetic results. Two men presented with auricular masses, with no history of trauma or tumors in the auricle. Laterally protruding masses were located around the helix and antihelix, which were similar in appearance to the normal auricular cartilage. We made an aesthetic skin incision under local anesthesia, and carved the mass from the normal cartilage for pathological and cosmetic reasons. Both excised masses showed MD of the auricular cartilage. We report these two cases with a review of the literature.
\end{abstract}

Korean J Otorhinolaryngol-Head Neck Surg 2018;61(7):378-81

Key Words Auricle $\cdot$ Ear · Myxoid degeneration · Surgery.

\section{Introduction}

The auricle can be deformed by inflammation, trauma, and neoplastic conditions. Pathologically, myxoid degeneration (MD) is a phenomenon that involves a loss of connective tissue; it affects soft tissues, including the heart valves, knee ligaments, and skin. ${ }^{1-5)}$ The pathophysiology and patient demographics of MD are poorly understood. Only one four-case series of MD of the auricle has been reported. ${ }^{5)}$ It is difficult to distinguish MD from other masses of the auricle based on a physical examination or needle aspiration due to its homogenous nature and hypertrophied cartilage lesion.

Recently, we experienced two cases of idiopathic MD of the auricle. In this case report, we present these two cases, which

This is an Open Access article distributed under the terms of the Creative Commons Attribution Non-Commercial License (https://creativecommons.org/licenses/by-nc/4.0) which permits unrestricted non-commercial use, distribution, and reproduction in any medium, provided the original work is properly cited. were managed successfully, with a literature review.

\section{Case}

\section{Case I}

While being evaluated for Cushing's disease and diabetes, a 51-year-old man was referred to the Department of Otolaryngology to assess a palpable lesion in his right auricle that had been present for 6 months. The lesion was primarily located in the scaphoid fossa and extended to the antihelix (Fig. 1A). On palpation, it was hard, non-tender, measured $1.6 \times 0.8 \mathrm{~cm}$, and protruded from the normal auricle without edema. The overlying skin was smooth. The external auditory canal and tympanic membrane both appeared normal by otoscopy. There was no history of disease affecting his right auricle, including trauma or tumors. He had a history of social alcohol consumption and did not smoke. Although we 

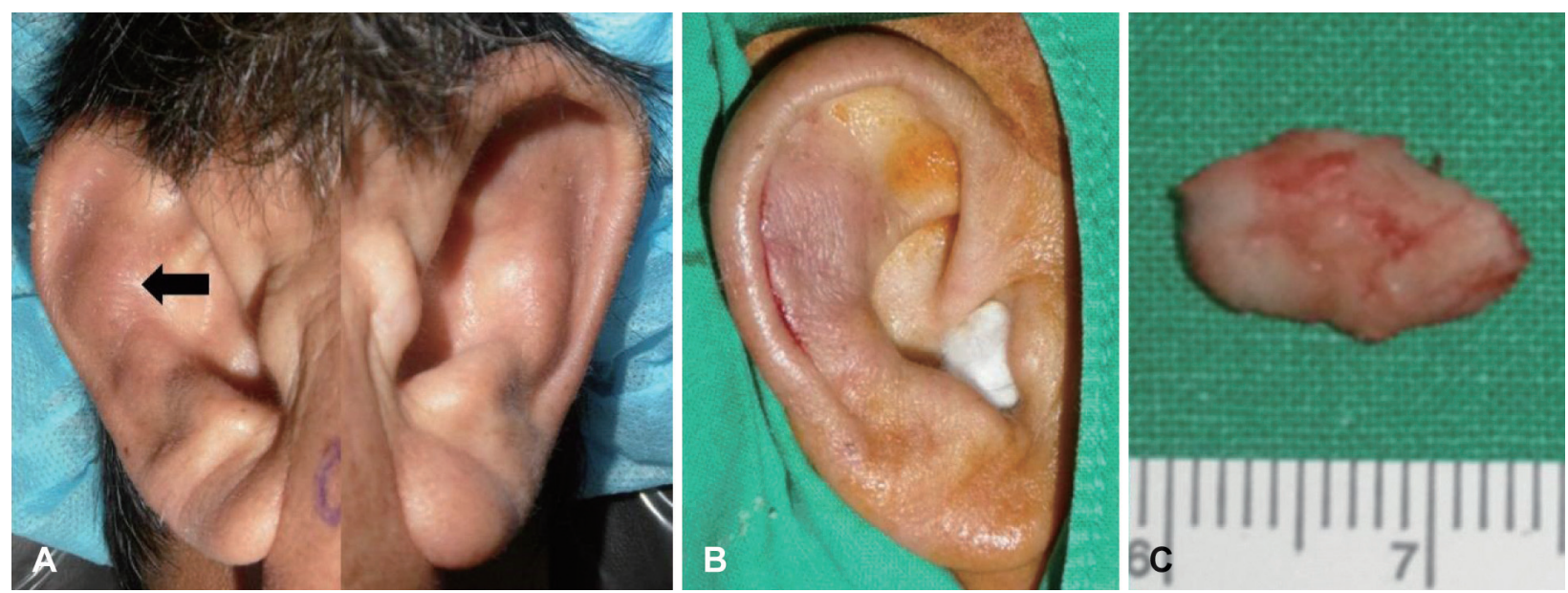

Fig. 1. In case 1, preoperative photos of both auricles showed a laterally protruding hard mass in the antihelix area (arrow) of the right auricle (A). After excision, the right auricle appeared normal (B). The excised mass measured $1.4 \times 0.6 \times 0.3 \mathrm{~cm}$ and was hard like normal cartilage $(C)$.

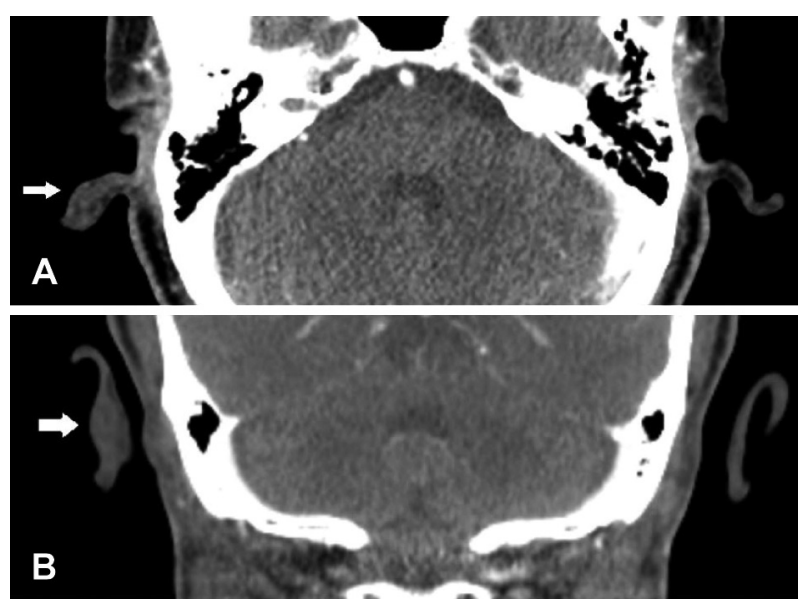

Fig. 2. In case 1, preoperative computed tomography revealed a mass that was hypodense to isodense with soft tissues in both axial (arrow, A) and coronal (arrow, B) views.

attempted fine needle aspiration for cytology, no tissue was aspirated. On computed tomography, the lesion had the same density as auricular cartilage (Fig. 2).

Suspecting a benign tumor, surgery was planned to obtain a pathological diagnosis and to correct the deformity for aesthetic purposes. Local anesthesia was obtained with an injection of 2\% xylocaine and 1:100000 epinephrine. After making a curvilinear incision along the anterior border of the helix, the skin was elevated and the auricular cartilage was exposed. Grossly, the lesion was almost identical to the surrounding normal cartilage. The upper end of the lesion was carved away with a no. 15 blade and extended inferiorly. Finally, the $1.5 \times 0.8 \times 0.3 \mathrm{~cm}$ lesion was removed totally and the remaining auricle appeared normal (Fig. 1B and C). The wound was closed primarily with 4/0 nylon. Pathologically,

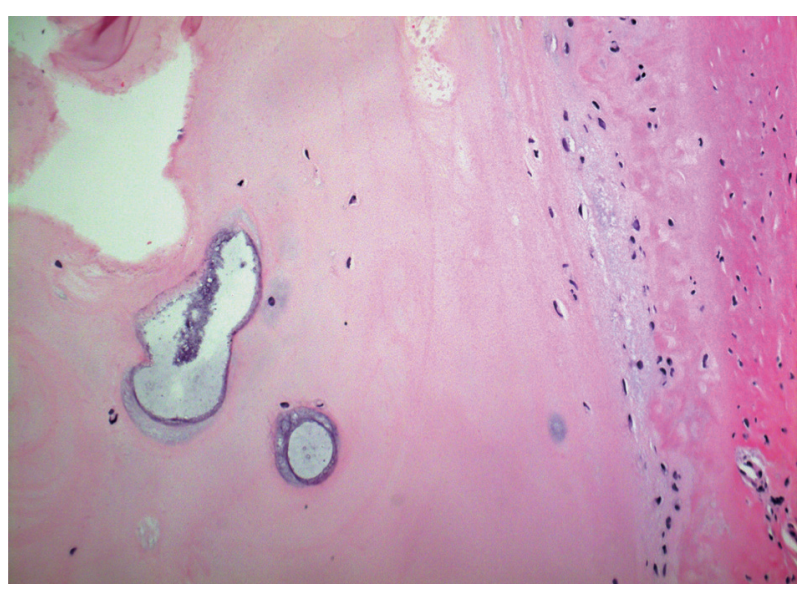

Fig. 3. In case 1, a histopathological section of the mass excised from the right auricular cartilage revealed myxoid degeneration of the catilage. No significant nuclear pleomorphism, mitotic figures, or necrosis was identified $(\mathrm{H} \& \mathrm{E} ; \times 100)$.

the specimen showed foci of MD with loosely arranged chondrocytes compared with normal cartilage (Fig. 3). There was no noticeable nuclear pleomorphism, mitotic figures, or necrosis (hematoxylin and eosin, $\times 200$ ).

\section{Case 2}

A 79-year-old man presented to the outpatient clinic of the Department of Otolaryngology with a slowly growing mass lesion in his right auricle that had been present for 3 years. The right auricle showed a non-tender, hard, $2.0 \times 1.5 \mathrm{~cm}$ mass with a smooth surface at the medial portion of the antihelix (Fig. 4). There was no specific finding on the otolaryngologic exam and no history of illness involving his right auricle, including trauma or tumors. He had a 25-pack-year history of cigarette smoking, but did not consume alcohol. 
Needle aspiration for cytology failed to aspirate tissue.

An operation was performed under local anesthesia for a pathological diagnosis and to correct the deformity. After making an incision in the antihelix, surgery was performed using the same methods as in case 1 . The lesion looked like normal cartilage anteriorly and a mix of cartilage and soft tissue posteriorly. It measured about $1.8 \times 1.3 \times 0.3 \mathrm{~cm}$. The pathology was similar to that in case 1 . Histological examination of the cartilage showed MD, which was similar to that in case 1 (Fig. 5).

\section{Discussion}

It is important to differentiate between benign and malig- nant auricle masses. Benign masses of the auricle include sebaceous cysts, keloid, hemangiomas, osteomas, and adenomas. Benign skin lesions of auricule include seborrheic keratosis, dermatosis papulosa nigra, epidermal nevus, and verruca vulgaris. ${ }^{6,7)} \mathrm{MD}$ is distinguished from most of these diseases by its characteristic clinical manifestations and pathology.

Idiopathic MD of the auricle is extremely rare, with only four reported cases. ${ }^{5)}$ In this report, MD of the auricular cartilage was characterized by overlying normal skin, no swelling or redness around the lesions, no aspirated cells on fine needle biopsy due to the similarity of tissue density with normal cartilage and the lesion arises within the helix or antihelix and mimics normal cartilage at surgery. An important factor in the differential diagnosis of auricular MD is suspicion when
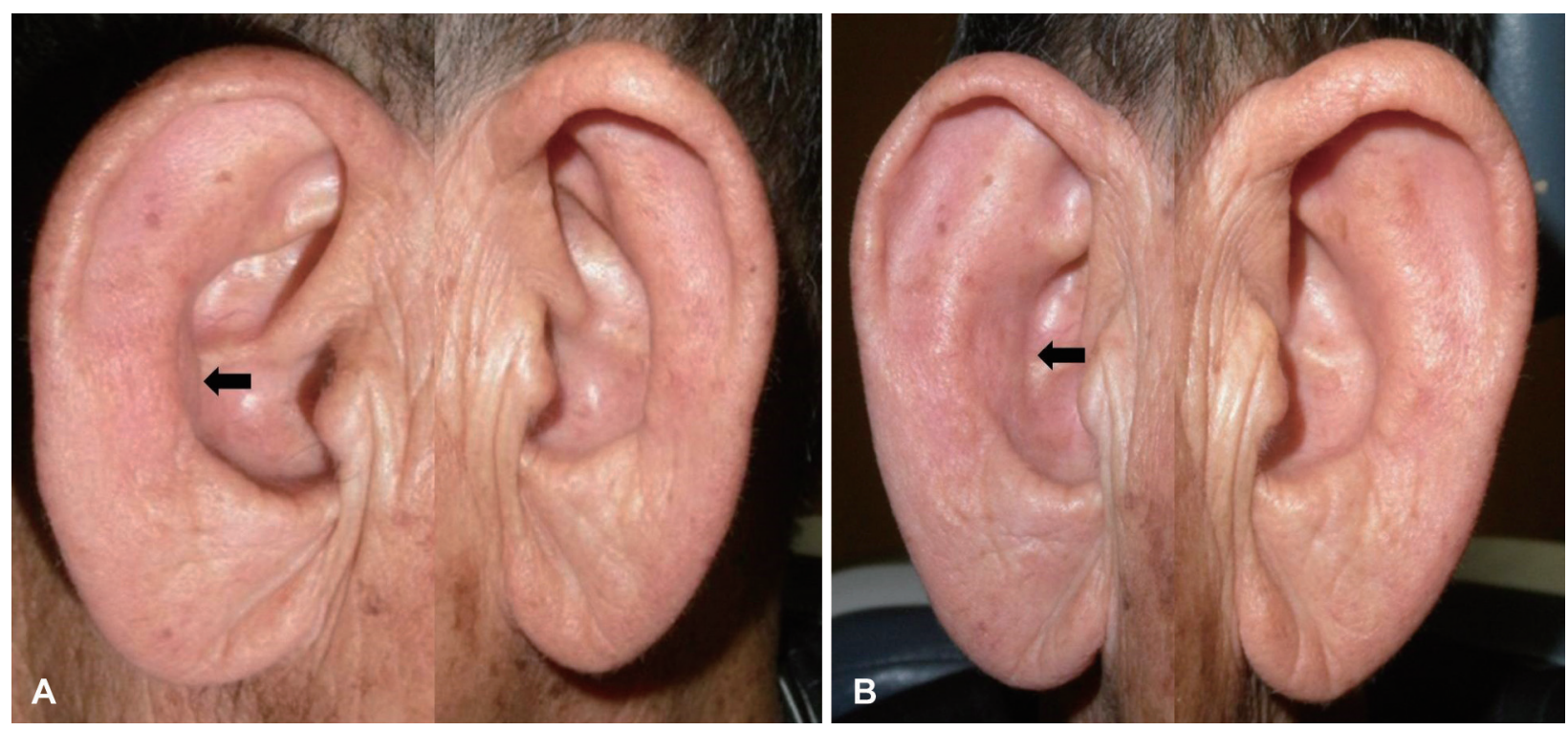

Fig. 4. In case 2, preoperative photos of both auricles showed an anteriorly protruding hard mass at the inner surface of the antihelix area (arrows) of the right auricle in lateral $(A)$ and oblique $(B)$ views.
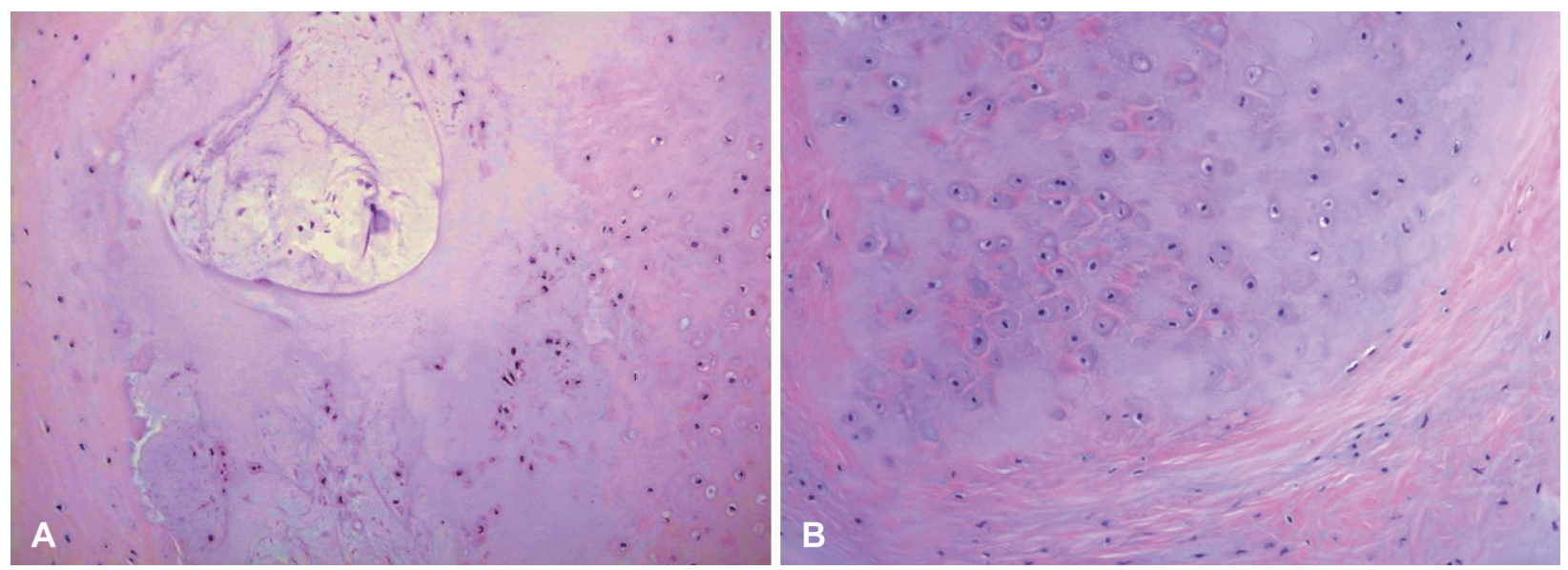

Fig. 5. In case 2, photomicrograph of the auricular cartilage revealed myxoid degeneration $(H \& E ; A \times 100, B \times 200)$. 
a mass is associated with those characteristics. After accumulating a large number of cases of MD in the auricular cartilage with long-term follow-up results, a presumptive clinical diagnosis could be made without a biopsy.

Considering our two cases and the four in Kean and Stewart, ${ }^{5)} \mathrm{MD}$ arose on the scaphoid fossa in five cases and the antihelix in the other. Occasionally, MD has been reported in the anterior cruciate ligament (ACL). ${ }^{2-4)}$ These patients were older, with a mean age of 43.6 years (range $35-79$ ), and the sex distribution was unclear. Generally, they had no history of trauma. Pathologically, in the ACL, MD manifests as a homogeneous, taut, hypertrophied ACL with yellow degenerative lesions. ${ }^{2)}$ Such findings are similar to those of auricle MD in our report and in Kean and Stewart ${ }^{5)}$ We believed that aging is the only possible cause of MD in the auricular cartilage. ${ }^{8-10)}$ Age-related structural changes in the outer ear include a general loss of elasticity and muscle tonicity. ${ }^{11)}$ These structural changes in the external or middle ear may alter the external ear resonance in the elderly. ${ }^{12)}$ A large case series might help to answer this question.

Generally, MD is a benign asymptomatic condition. Kean and Stewart ${ }^{5}$ achieved good aesthetic results by hand carving the mass via a scaphoid rim incision, which is inconspicuous and secures good exposure. We also achieved good aesthetic results without causing auricle deformity. We believe that surgical approaches should focus on confirming the pathological diagnosis with minimal aesthetic effect. This is the second report of MD of the auricle, presenting two cases. Additional studies are needed to discover the pathophysiology of MD in the auricular cartilage.

\section{REFERENCES}

1) Gagna C, Meier D, Ru G, Pospischil A, Guarda F. Pathology of mitral valve in regularly slaughtered pigs: an abattoir survey on the occurrence of myxoid degeneration (endocardiosis), fibrosis and valvulitis. Zentralbl Veterinarmed A 1998;45(6-7):383-95.

2) Cha JR, Lee CC, Cho SD, Youm YS, Jung KH. Symptomatic mucoid degeneration of the anterior cruciate ligament. Knee Surg Sports Traumatol Arthrosc 2013;21(3):658-63.

3) Narvekar A, Gajjar S. Mucoid degeneration of the anterior cruciate ligament. Arthroscopy 2004;20(2):141-6.

4) Pandey V, Suman C, Sharma S, Rao SP, Kiran Acharya K, Sambaji C. Mucoid degeneration of the anterior cruciate ligament: management and outcome. Indian J Orthop 2014;48(2):197-202.

5) Kean J, Stewart KJ. Remodelling of the pinna in myxoid degeneration of the ear. J Plast Reconstr Aesthet Surg 2010;63(7):e556-60.

6) Brodsky J. Management of benign skin lesions commonly affecting the face: actinic keratosis, seborrheic keratosis, and rosacea. Curr Opin Otolaryngol Head Neck Surg 2009;17(4):315-20.

7) Bruggink SC, de Koning MN, Gussekloo J, Egberts PF, Ter Schegget J, Feltkamp MC, et al. Cutaneous wart-associated HPV types: prevalence and relation with patient characteristics. J Clin Virol 2012;55(3):250-5.

8) Makino A, Pascual-Garrido C, Rolón A, Isola M, Muscolo DL. Mucoid degeneration of the anterior cruciate ligament: MRI, clinical, intraoperative, and histological findings. Knee Surg Sports Traumatol Arthrosc 2011;19(3):408-11.

9) Fernandes JL, Viana SL, Mendonça JL, Freitas FM, Bezerra AS, Lima GA, et al. Mucoid degeneration of the anterior cruciate ligament: magnetic resonance imaging findings of an underdiagnosed entity. Acta Radiol 2008;49(1):75-9.

10) Krudwig WK, Schulte KK, Heinemann C. Intra-articular ganglion cysts of the knee joint: a report of 85 cases and review of the literature. Knee Surg Sports Traumatol Arthrosc 2004;12(2):123-9.

11) Nerbonne MA. The effects of aging on auditory structures and functions. In: Shadden BB, editor. Communication behavior and aging: a sourcebook for clinicians. Baltimore: Williams \& Wilkins;1988. p.137-61.

12) Liu TC, Chen YS. Aging and external ear resonance. Audiology 2000; 39(5):235-7. 